\title{
DEMOCRACY IN CAGE: TOWARDS A FRAMEWORK FOR A STATE RESTRUCTURING IN NEPAL
}

Tulsi Ram Pandey*

\section{Introduction}

"State Restructuring" has appeared as one of the important issues currently in vogue in public debates of Nepal. The "People's War" waged by $M$ aoist political organization against existing system of governance has been the most important contributory factor to intitiate this type of debate. The failure of existing state organization to settle the issues raised by people by way of this rebellion is also equally responsible for further stimulating this debate. However, a chain of political events happened in the country in a series of sequences during the period covered by this rebellion. Consequently, there has been a progressive growth in the number of participants involved in this debate and the type of demand posed by them towards restructuring the state.

Indeed, state restructuring is a continual process. It appears in all systems of rules at all contexts and conditions. In the case of $\mathrm{N}$ epali state, the need to reformulate its structure formed after the termination of Panchayat rule in 1990 was formally voiced for the first time by Samyukta Janamorcha (United People' Front) party in 1996. It had done so by placing a forty-point demand in this regard before the government. However, it was a political organization which itself had representation in the then parliament of the country. As a political force sharing power of existing state organization, it was unable to take any effective strategy to pressurize the state for the fulfillment of this demand. Later on, the

\footnotetext{
* Tulsi Ram Pandey holds Ph. D. in Sociology from D elhi U niversity, India. Currently, he is an Associate Professor in Sociology at the Central Department of Sociology/ Anthropology.
} 
issue was raised more vigorously by $\mathrm{N}$ epal Communist Party $\mathrm{M}$ aoist (NCPM). It was a political organization operating from outside the framework of prevailing system of governance. It placed its demand in the form of a revolution wedged against that political system.

Until a political movement was launched collectively by a number of political organizations in A pril 2006 against the active rule of monarch, NCPM was the only organized force of the country to make effective demand for the need of a restructured state. A s a political force operating from outside the structure of existing state organization, its activities and hence its demands for restructuring the state were defined by all other types of political forces belonging to the establishment side as "terrorist" activities until this time. The political instability faced by people under such a belligerent situation gradually provoked the interest of intellectuals, media-persons and civil society personnel in their personal capacities to participate in this type of debate.

The king had established his active rule on 40 ctober, 2002 by dissolving the "representative" form of elected government. Even after this event, he had provided an opportunity almost rotationally for more than two years to leaders of different political organizations, which were in power before this event. This strategy of the king allowed The auther would like to mention that the earlier version of his paper was presented in the International Conference on "Social Sciences in a Multicultural World" held in Kathmandu in December 2006.an opportunity for some political leaders of these organizations to satisfy their interests at least personally. Consequently, issues related to restructuring the state could not emerge in the form of a unified agenda of those organizations until the king took a next step in 2005 to reduce further their political role in the state apparatus.

The king, in February 2005, had taken a second step of his involvement into active politics of the country. He replaced the multiparty leaders from formal power structure and dragged in their place the political workers of Panchayat era. He formed the government under his own leadership and improvised to file the cases against many of the multiparty leaders alleging them of being involved into different types of corrupt behaviors. This move of the king created a suffocation for many of the 
multiparty leaders, as it deprived them from the opportunities to have share in formal structure of the power. Consequently, it motivated them to come together and develop a unified force to go against the king's move.

The political movement launched in A pril 2006 was an outcome of such a situation. It was a unified attempt initiated by leaders of seven political organizations, which were in power before this time. This type of political effort gained support even from the Maoist organization, which was labeled as "terrorist" until that time and from the activists of different types of civil society organizations. Such a combined effort made by these different categories of forces became able to deactivate the political role of the king.

The political forces which formed this unity to go against the king had, however, no uniformity of interest among themselves. The diversity of interests among these political categories was not conducive to bring these groups into an easy type of compromise. Of course, their victory against the power of the absolute king has opened the chances for diffusion of power of society into multiple types of political categories. However, this type of diffusion of power also made the political atmosphere very liquid in society in the absence of a structural mechanism that could harmonize these diversities.

The advantages available from such a liquidity developed in political environment are now being tapped by both political and non-political types of social organizations. They have started to place their demand on the type of structure they want to see in the Nepali state. Some of these social units want the state to have a structure that could solve the problems rooted in caste, ethnicity, region, religion and gender-based divisions of the population. Some others want its reformulation in such a way that it could increase the facilities provided to people. The political forces that were helping the king to suppress the movement launched against him have also started to tune up their voice in favor of the need for restructuring the state. The Comprehensive Peace Agreement concluded between the State and the NCPM in November 2006, their endorsement of an Interim Constitution requiring to form an elected body of Constitutional Assembly vested with the authority to prepare 
constitution for the nation, together with the formation of such an assembly through the completion of such an electoral procedure have all contributed to convert the issues related to "restructuring the state" in the form of formal political agenda at the moment.

There is no question that all the political and non-political categories participating in this debate have an interest to see a restructured state. They all agree to a point that such a restructuring is necessary due to the failure of existing state organization to operate in democratic way. However, the diversity of interests among different types of social categories in matters of their relation to the restructured state has posed a question as to what should we mean by the state itself and about its democratic procedures. Given this context, it is important, firstly, to be familiar about the meaning of social reality symbolized by these concepts. It would, then, be appropriate to explore the reasons of the failure of existing structure of state organization to satisfy those processes. It is also important in this moment to evaluate the extent at which the current demands for restructuring the state are contributory to satisfy those processes.

In this regard, this essay is organized as follows. The next section immediately following this introduction highlights on the meaning of the state. The third section seeks to understand the meaning of democracy and/or the democratic processes. The fourth section aims to discuss on how the democratic processes were kept into cage by all previous waves of efforts towards restructuring the state. The fifth section intends to evaluate the contents and implications of current debates on state restructuring in $\mathrm{Nepal}$ by relating them with the characteristics of those democratic processes. The last section concludes the paper by identifying some additional issues of importance that deserve to be discussed.

\section{Meaning of the State}

W eber defines the state as "a human community that (successfully) claims the monopoly of the legitimate use of physical force within a given territory" (1948:77-78). Hobbes is of the conception that such a community is needed for humankind to relieve itself from the problems associated with its life in the state of nature, which appears "solitary, 
poor, nasty, brutish and short" (quoted in J ordan 1985: 26). A lternatively, it is required, as perceived by Lock, to preserve the natural right of equality and freedom gifted by god to all members of this human population as they were in the original state of nature (Dunn 1969). There are, of course, no uniform views as to the reasons for the emergence of state as a form of human community. All of those who have expressed their views in this regard have an agreement that it exists by the very fact of human need for having a sovereign institution that is able to pose some limits on activities of members of the humanity as is required for the protection of their own rights and promotion of their welfare and abilities.

There are no uniformities of tasks performed by individual states working in different types of social situations. As a result of these differences of tasks of the individual states, there is no uniformity of the meaning of this institution in different types of contextual situations. The contextual differences of the meaning of the state can be grasped much adequately by identifying this meaning through conceiving it in the form of an institution, organization, class and processes.

The state as an institution is the repository of supreme power over the people and resources located within a territorial unit. This supremacy of power enjoyed by the state is manifested in its authority to formulate rules and regulations prescribing for patterns of behaviors of those people and for control and distribution of those resources. It retains ultimate right to implement those policies and rules into practices. In this process, it can resort even to use of physical force to oblige people and other types of their institutions located within its territorial domain to abide with those rules. However, individual states may hold no uniform types of objectives and obligations to the people. Consequently, there may be differences of policies and rules of the states formulated by them to satisfy those objectives.

The ultimate authority hold by the state makes it solely responsible to arrange for the maintenance of law and order in society. M aintenance of law and order is the conventional role of all states. M ost of the rules formulated and implemented by this institution in all contexts are geared towards the fulfillment of this role. However, the growth of marketbased activities in economic spheres of life in societies, the expansion of 
these activities across the boundaries of local communities, the formation of nation states in different parts of the world as a result of political processes induced by the expansion of this economic process, and the needs of these states to come into contact with each other in defense of the interests of their own and their respective population have demanded them, at least recently, also to involve in developmental practices.

The developmental role of the state can be understood by classifying them into regulative and investment oriented categories. Since the beginning of market based transactions in the economies of European continent, involvement of the state has remained highly expected to formulate rule and regulations in support of operation of the market. The emergence of socialist economy in Eastern Europe after October Revolution of Russia and the adherence to welfare state model of economy by many states of the world following Keynesian ideas boosted up the involvement of these states to formulate plans and programs for related change of their respective societies. The beginning of the era of foreign added "development" induced in developing countries of the world by cold war politics following the Second W orld War further required these states to define the path of change of their societies in line with interest of donor communities.

The developmental roles of the state are, however, not confined only to regulative tasks. In many contexts, they have been actively involved as entrepreneurs in activities requiring investments from their parts. This type of involvement is not a recent experience in many of the nation states. As early in the eighteenth century, A dam smith, the founding father of liberal economic ideas, was himself of the view that the states would have to invest in the development of human capital and other type of infrastructural services for the promotion of market-based economic activities in their respective societies (Rosenberg, 1960). He had recommended that it can use even the physical force, if required, in support of entrepreneurs to expand these activities. Indeed, colonial rules in many parts of the world were established by the liberal states. They had accomplished this task through military encroachment in technologically weak areas. They had followed this strategy to convert these areas as a source of raw materials and as markets for commodities produced by entrepreneurs of their own societies. 
In socialist economies like those in China, Cuba and others, the states have remained as owner of most of productive resources of their respective societies. They are engaged in use of those resources in production processes and distribution of goods and services produced through those processes. Even the liberal states which are sensitive to present themselves in an image of the "welfare state" have begun to operate as the sources of financial capital, investors on major infrastructural services, purveyors of basic facilities and resources, and the suppliers of a number of social services including social security measures to people of their respective areas.

The policies and rules are the manifestations of ideological commitments made by the state at its institutional level. However, it requires a set of organizational structures for the formulation of those policies and rules and implementing them into practices. Taken in this context, the state is also "a set of organizations invested with the autonomy to make binding decisions for people and to implement those decisions" into practices as needed (Ruschemeyer and Evans 1985: 66-67). A ccordingly, we can observe the state in the form of a structure having different types of organizations deputed with tasks to perform legislative, executive, and judicial functions needed to fulfill its institutional objectives.

These organizational sets are distributed to different layers of hierarchies from the centre of power to micro level units like villages. The type of objectives defined for a state by way of formulation of its policies prescribes the shape of its organizational structure required for the implementation of those policies. This is the reasons why we encounter a number of variations in the organizational framework followed by states in different types of societies. Some of these differences can be noted in the form of unitary or federal types of state organizations, monarchical, military or multiparty type of their organizational arrangements, together with the specific framework of their bureaucratic organizations. In the case of $\mathrm{Nepal}$, these organizations are distributed to central, regional, district and village level units.

The state needs a crew of officials to run these organizations for the fulfillment of its tasks. In this context, the state may be defined also as a 
ruling class of society placed in different positions of power distributed in hierarchies of organizations established within its structure. Of course, there are differences in the volume of power and other types of privileges enjoyed by individual members among these officials. However, they all assume the characteristics of a class in view of the fact that their power and privileges are derived from their membership in this ruling segment of the population. Their characteristics as a class are manifested also in the sense that the interests and initiatives taken by these officials highly influence the objectives of the state and its operational strategies. The state is, therefore, a specific pattern of relationship of these officials with the people. Differences found among states in the pattern of such a relationship determines the differences of their forms. The democratic, feudal, military or any other types of dictatorial rules are the ministrations of differences of forms of this type relationship found between the state and the remaining part of its society.

The state also defines a set of procedures for its staff and organization to follow in the course of their operations. It also defines the procedures of relationships of those staff and agencies with general mass of the population. In this context, the state is also a process of relationship of its staff and agencies with the people (M igdal, 1988). Differences of processes prescribed by different types of the states for their staff and agencies in their relations with the people reflect the differences of their forms. It is this type of difference that some states appear much dictatorial to take the form of what Hobbes calls a Leviathan state. Some others allow some level of freedom to their respective population and manifest themselves into the form of a democratic state.

\section{Democracy and the Democratic State}

Referring to fields covered by the broader concept of socio-economic "development", Sen perceives the meaning of this concept in terms of "freedom" (Sen, 2000). While freedom taken in this broader sense of development denotes to a particular pattern and process of distribution, control and use of power among members within and between all categories of social units, "democracy" as a term has been used to denote the features of those patterns and processes as they occur in the context of operation of the state. A democratic state is, therefore, the one that 
exercises a minimum level of control over the activities of its citizens and democratization is a process of political development leading to formation of a democratic state.

One important criterion which is normally used to identify democratic status of a state is the locus of sovereign power exercised by this institution. In a democratic state, as mentioned above, people are considered to be the source of such a sovereign power. Based on this criterion, the states in which such a power is located in the hand of a ruler or ruling groups of the population are termed as authoritarian or the dictatorial states.

However, the authoritarian or the dictatorial forms of the state also differ among themselves in terms of the patterns of their organizations and the mode of their exercise of power. One such a variety of this category of the states is represented by the feudal states. In feudal state, authority structure is established in a chain of hierarchy formed on the basis of differences of power over the control of productive resources, particularly the land. In this type of the state, sovereign power is rooted in the hand of the ruler placed at epicenter of its authority structure. This ruler, as a source of sovereign power, is also the owner of productive resources available in respective society. It distributes these resources in the form of various types of grants and assignments to its own relatives, different grades of nobilities, and functionaries of the state in exchange of their loyalties. The general mass of the population is provided with a means of subsistence to work on them in the payment of tax and various forms of rents to these rulers, nobles and functionaries.

The sovereign power, even in military or other forms of dictatorial rules, is located in the hand of rulers placed at epicenter of power. However, the strength of these rulers is generated either on military might of the country or on organized bureaucracy established in their own command. Indeed, all the above mentioned forms of state structures -- feudal, military or other dictatorial/authoritarian forms -- are dictatorial in nature in the sense that the state structures in those systems are formed to dictate the interest of those rulers. However, the state having feudal type of structure is possible only in agrarian societies. The military or any other forms of dictatorial rules embedded on organized bureaucracy can exist in agrarian, industrial or any other forms of advanced economies. 
Scholars have held a perception that the multiparty type of political and administrative structures found in countries like the United States, U nited Kingdom and others retain many democratic features. They retain this perception in view of the fact that the systems of rules established in these states take people as the source of their sovereign power. They also hold the belief that multiparty types of political processes allow the people to exercise this power by way of electoral process. Through participation in this process, they can elect the representatives of their choice to formulate rules and regulations required for the operation of the state (Hood 2004, Lindblom 1988).

There is no doubt that the recognition provided by any state to its people as a source of its sovereign power satisfies one important type of its democratic character. Similarly, people can avail an opportunity to exercise this power by way of electing their leaders through participation in politics of votes only in states having some level of democratic features. However, it is misleading to consider that the opportunity available for people to participate in such an electoral process can serve as the sole criterion for defining a democratic structure. Participation of people in electoral procedure mainly helps to legitimize the path of access to power for political elite of society. Whether such a participatory process becomes able to be translated into democratic practices depends upon the behavior of elected leaders. It is not unlikely that this group of elite, after being elected through such an electoral procedure, may seize this opportunity to frame the structure of the state and its rules for its own advantage.

Evidences in regard to formation of such a class in the state have been discussed much elaborately by scholars even for the case of states adopting multiparty type of political practices (Miliband, 1969). These scholars have put forward the arguments that even in countries like the Great Britain and the U nited States of A merica, voting practices are followed in the form of a means for mirroring the existing balance of power situation among elite group of society. The elected "representatives" in these states form a corporate power and act to suppress the interest of general people by formulating policies and rules in favor of bourgeoisie (Jessop 1990, Poulantza 1973).

Such a situation opens the possibility that even the states favoring multiparty type of political structures may emerge into multiparty type 
of dictatorial rule. Democracy in this context should be viewed not only in terms of processes established for access to power, but also in terms of outputs of the state. It should be measured also in terms of issues related to responsiveness of its structure and its elected group of political elite to the interest and needs of people who have voted for them to legitimize their stay in the power structure of the state. This type of issues covers a wider field ranging from the forms of policies and rules of the state, its organizational structure, and ways followed by it for implementation of those rulers that affect the life of its people.

If the features of a democratic state are measured in terms of the means prescribed for elite to have access to positions of power on its structure and also in terms of the type of policies as well as their implementation procedures followed by it to affect the people, the boundaries between democratic and dictatorial type of states may not be tightly closed to each other. They may share some features in common that "democratic" and "dictatorial" tags have to be fixed in the scale of a continuum for any type of the states after measuring their specific features. Indeed, history has shown that the feudal aristocracies or the bourgeois in some context of East A sia and Western Europe had taken charge in themselves to replace the authoritarian type of feudal political structure by multiparty type of political rule (Moore, 1966).

This type of argument gets some level of support from some existing facts of societies. We can notice that a wide variety of states following different system of governance make a claim for themselves to have the democratic structure. Some of these systems include the "Panchayat Democracy" of pre-1990 Nepal, "Basic Democracy" of Pakistan, "People's Democracy" of socialist states like China, North Korea and others, and "M ulti-Party Democracy" of India, Japan, U nited Kingdom, United States of A merica and a host of such others.

These states make such a claim in view of the fact that they possess either or some of the following democratic ideals. They may have: (a) recognized the people as a sources of sovereign power of the state; (b) allowed them to participate in competitive political processes; (c) formulated at least some rules and regulations addressed towards making a positive change in conditions of life of the population; (d) established 
an administrative order congenial for implementing those regulations, and (e) set some specific procedures to ease the people in taking services from the state. While a democratic system needs to have all these ideals, it is important to measure the degree at which $\mathrm{N}$ epali state in the past retained these ideals within its structure and operational procedures. This type of measurement will be useful to find justification of current demands for restructuring its structure.

\section{Democracy in Cage: An Overview of the Structure and Operational Procedure of the Nepali State}

It has already been mentioned that current demands for restructuring the $\mathrm{N}$ epali state are the demands for strengthening its democratic processes. These types of demands are not necessarily new in the history of this state. State restructuring as a political event has occurred in $\mathrm{Nepal}$ in a series of sequences since the beginning of its territorial unification process. This process was initiated by King Prithivi Narayan Shaha of Gorkha principality around the middle of $18^{\text {th }}$ century. Since then, a number of political events have happened in the country affecting the structure of the state. In the scale of a continuum of the features of democratic or dictatorial rules, all these events towards restructuring the Nepal state can be understood much meaningfully by classifying them into four different waves.

The political events that come into sight with an appeal towards restructuring the $\mathrm{N}$ epali state in all period before 1950 may be termed as events of the first wave of its restructuring process. Indeed, the territorial unification was itself one important event of this wave of political process. It brought together a number of small principalities to give the shape of a single Nepali state (Stiller, 1973). There used to appear a number of clashes among different factions of the nobility in the processes of their search for power of the state. The shifts of favor received from the king also used to create a shift in the factions of nobility having access to that power. At occasions, some factions of the nobility also used to keep the power of the king in suspension and rule the country by themselves in his name (Kumar, 1961).

However, the operation of the state through all this period was 
grounded in feudal type of political and administrative structure. The king was regarded as a source of sovereign power of the country. He was the ultimate owner of resources existing within its territory. He used to distribute these resources such as land and forest to its relatives, nobility and various grades of its functionaries to gain their support and loyalties (Regmi, 1978). Even when some factions of the nobility seized power from the king by keeping his active role into suspension, they also followed similar type of political and economic practices to entrench their own power in the state.

There was a sharp divide of status and opportunities enjoyed by members of this ruling class and mass of people. This type of division was not based on competitive successes gained through achieved qualities and status. Rather, they were grabbed by members of this class by virtue of their ownership of the state and hence its power. The relationship of masses with this ruling group of society was mediated mainly by fixing them a number of liabilities to pay for various grades of these overlords. The state had not granted any right to people to participate in political process. It had not taken any responsibilities to involve itself into tasks addressed towards improvement of condition of life of those subject communities. It was completely a dictatorial state organized under the feudal structure.

The political events that happened in the country around and during the 1950s may be termed as the second wave of $\mathrm{N}$ epal's state restructuring process. The events that happened in this period dismantled the oligarchic type of feudal dictatorship of the Ranas. The Ranas were one important faction of nobility. They came into epicenter of power in 1846, and from 1854 onwards, they managed to keep the active role of the king into suspension. By seizing his de facto power, their families ruled over the country for more than a century until a political movement threw them out from power in 1951.

The political movement against the Ranas was launched by an urbanbased educated middle-class of the population. This section of the population was the one which had no share in formal power structure existing in the country before this time. The leaders which had managed to launch this political event had sought some support even from the 
King who was denied by the Ranas to involve into active type of politics. As a result, the downfall of Rana rule brought two different types of forces to operate in political life of society.

One such a force was represented by the king. His political role no longer remained into suspension. He was placed into his original place as a sovereign head of the state. A nother type of political force was represented by the multiparty leaders. They were representing the emerging political force of society. There was no space for this force under existing organization of the state. A separate political niche had to be carved out for the accommodation of this force. This task was accomplished through the introduction of the multiparty type of political structure. This was the major event of this second wave of Nepal's state restructuring process.

The introduction of multiparty type of political structure helped to inject some democratic ideals into political sphere of society. It no longer allowed the politics of the nation to remain into property domain of the nobility. It opened an opportunity for the expansion of ruling circle of society. It demanded that the political leaders be recruited to run the government through electoral procedures (Joshi and Rose, 1966).

The electoral type of political procedures required for the recruitment of governing elite of society made it necessary for them to win the favor of people to get access to power. The pressures generated by such a requirement motivated them to bring some changes also in the objectives and activities of the state. Now the role of the state was enlarged. At least in theory, it was obliged to commit to take some developmental responsibilities, apart from its conventional role for the maintenance of law and order in society.

In line with this redefined role of the state, the governments represented by multiparty leaders during the 1950s made it mandatory for the state to involve into "developmental" practices through the introduction of a planned process (Stiller and Yadav, 1979). They formulated rules to establish an organized bureaucracy in view of its need to implement those processes (A grawal, 1976). They also formulated policies and rules aiming at reforms of existing agrarian structure. 
However, the king and the multiparty leaders could not go beyond the formulation of these policies and regulations. The king was always eager to retain back his absolute position into power. The multiparty leaders also battled among themselves and hold the conception that their access to power was itself an indicator of the fulfillment of all goals hold by them during the process of their political struggle. Consequently, politics of Nepal during the 1950s' witnessed an intense struggle for power among these different categories of its stakeholders.

One such a conflict was that between the king and the multiparty leaders. The king always wanted to weaken the multiparty procedure. He was strongly convinced that the opportunity for his absolute control of power would be possible only through breaking the chances of any level of unity of the multiparty force. Accordingly, he adopted a strategy to allow the leaders of different political organizations to form the government on a rotational basis.

A nother type of conflict appeared among the multiparty leaders. Their hunger for power could not make it feasible to develop a common political agenda of the multiparty politics (Gupta, 1964). Thus, democracy during the 1950s emerged in Nepal mainly in the form of a political ideology. The king and the multiparty leaders kept this ideology into cage and struggled among themselves for the stability of their access to position of power. The administrative structure remained highly centralized. The developmental programs, if implemented, could not appear in the form of regular activities of the state, but were used only in the form of their patronage. The king took advantage of such an unstable political situation. In 1960, he dissolved the multiparty type of political processes and seized all executive powers of the country to exercise it by himself in absolute terms.

This step of the king may be taken in the form of the third wave of state restructuring in $\mathrm{N}$ epal. In one sense, it was a retreat from the democratic ideals introduced in the country after the downfall Rana rule. Through this move, he blocked the operation of plural type of political organization and introduced one party type of Panchayat rule. However, the king was fully aware of the fact that it would be difficult for him to establish the legitimacy of this move without showing the commitment 
that the governments headed by him were also sensitive to the problems faced by the people. Consequently, he gave continuity to the process of implementation of planned development practices. He did not lag behind to give his government a hue of representative character. In this process, he divided the country into a number of political units and introduced an electoral procedure to select his supporters required to run them. He also established a tightly organized bureaucratic structure by dividing it into central, regional, zonal, district and village level units (A grawal, 1976).

It is true that some of the steps taken by the king towards restructuring the political and administrative organs of the government made a longlasting effect to shape the organizational base of the state. The organizational structure operating in the country even today owes its origin to that established during Panchat period by the king. This type of structure was created to extend centralization of power of the monarch in different parts of the country. It was mobilized for the control of local level resources and for the expansion of terror of power of the monarch in different sectors of society.

The king's strategy to expand political and administrative structure of the country enlarged the volume of ruling class and his supporters in society. It enlarged the size of that segment of the population who could have a share over the perquisites distributed by the state. The political supporters which were recruited by the king had to come through facing an electoral procedure. However, they had to attend this competitive process only in term of differences of their personalities rather than that of their values and objectives. They had the duty to fulfill the interest of the king through working under his absolute command. The bureaucratic structure of the country was used to implement this command into practical fields.

Therefore, the state class working in Panchayat period was responsible to the king and not to the people. It owned the institutions and activities of the state on behalf of the king and used them to satisfy its interest and to legitimize the need of its own existence. The result was that, the development programs implemented during this period retained the status of rutinized tasks, or annual or periodic regularities 
of activities of this class. They could not emerge in the form of wants and rights of people distributed in different sectors of society. They appeared as targeted tasks implemented by members of this class to legitimize its existence.

The developmental activities implemented under the ownership of state class of the country resulted to promote a number of disparities. For those deriving perquisite from the state, or others having access to sufficient amount of resources, they were supplied with multiple options for enjoying the luxuries. They opened roads and established the markets for bringing different qualities of consumption materials to the doorsteps of their houses. They opened opportunities for them to earn cash through investment on supply of these materials to different corners of the country. They also opened an opportunity for this segment of society to invest on educating their children in advanced academic institutions enabling them to become the members of this class in the generations to come. They reduced the rate of mortality of their children and ensured them with the guarantee for having the comfort of living in small size family.

For the poor and marginal sections of the population, the developmental activities implemented under ownership of this class contributed to increase relative level of deprivation and poverty. The expansion of market exposed them with additional types of consumption necessities and increased the economic burden of their respective families. This event also led to reduce the local employment opportunities by compelling the indigeous enterprises to decline in face of competition with market-based commodities. The decline in indigenous enterprises together with the decline in mortality rate of the population increased the volume of unused labor in their families, reduced the per capita size of their resources, and increased the level of their poverty. Such a situation forced them to reclaim on marginal type of resources or to migrate out of the country in search of income and employment to satisfy their subsistence necessities.

The multiparty leaders suspended by the king during the Panchayat period took this misery of the people as a motivating force to generate their support to wedge a political movement against the Panchayat rule of the king. The termination of Panchayat rule and the reintroduction of 
multiparty type of government in 1990 was an outcome of such a political move. With the introduction of multiparty type of political structure, the $N$ epali state inserted new democratic ideals to be followed within its structure. As a result, this type of political event may be said as the fourth wave of state restructuring in Nepal.

The democratic ideals introduced by the Nepali state during the post 1990 period may be understood by breaking them into institutional, organizational and procedural levels. At the institutional level, the state after this political event recognized people as a source of sovereign power of the country. It reduced the king into constitutional status. It eliminated all legal barriers on people's right to freedom of expression and organization. Hence, it entertained political pluralism in the country and opened opportunity for people to organize into different types of political, social and cultural units.

W ith these changes in institutional values of the state, some changes were made also in its organizational character. Particularly, it established multiparty types of political organizations as the pillars for the conduction of political activities of the country. It also incorporated some caste, ethnicity and gender-based social and cultural organizations in the form of its structural units.

The installment of multiparty type political structure also produced some changes in its operational procedures. It required the political leaders to go through electoral processes to have access to power. Unlike in Panchayat system, these types of elections were to be faced not on differences of their individual personalities but on that of their political values and ideological goals.

These changes in ideological components as well as in structural elements of the state made some tangible effects on reorganization of ruling class of society. Particularly, the introduction of multiparty type of political structure displaced the Panchayat leaders from the positions of power. It installed multiparty leaders in those positions and enlarged the population of this class. The opportunities for the enlargement of ruling class of the population was further enhanced through the incorporation of some caste, ethnic and gender-based social units within the structure of state organization. 
The opportunities opened by the state through its ideological commitment to follow democratic values in its operation were harnessed quite adequately by the state class of $\mathrm{N}$ epal. Indeed, the freedom provided by multiparty type of political structure for the enlargement of this class was itself one important type of advantage available from the state for this class. This type of opportunity helped to expand the volume of that segment of the population who could derive some privileges through occupying the positions of power. Together, the state class of $\mathrm{Nepal}$, even in the post-1990 period, derived some other types of advantages through the use of these privileges and power.

It used the freedom of emerging type of "democratic" environment to mobilize its power to formulate policies and rules to allow the members of the class to import luxuries of life on a tax-free basis. It used this power to create opportunities of foreign visits for its members in reward of their commitment to keep continuity of their membership in the class. It also used this power to increase the level of other types of facilities and privileges supplied for them from the state to enhance the comfort of their life.

However, the democratic ideals committed by the state were manifested only nominally if they are evaluated in the context of relationship of this class with people. The multiparty leaders developed a misconceived notion that the sole criteria for defining a democratic type of socio-political structure was the level at which it provides chances for members in the elite to file their candidacy in elections and for people to caste their votes in favor of candidates of their choice through participating in those electoral processes. .

The adoption of competitive type of electoral procedure is, of course, a form of democratic practice in itself. It offers opportunities for the potential claimants of power to occupy related positions of society in circular way through allowing them to contest on election in a competitive basis. However, the general mass of people experience the advantage of such a competitive political process only in the form of activities performed for them by those leaders' communities.

The multiparty leaders considered the periodic electoral process (and the success emanating from it) as an end in itself rather than a form 
of responsibility and behavior. They were interested mainly to bring a change in elite circle of society. In matters of their relationship with people, they followed political values and administrative procedures similar to those followed by leaders of the Panchayat rule.

They inherited without change the administrative structure developed by the king in Panchayat period. They inherited from Panchayat rule the substance and strategies of developmental procedures. They also upheld the prevailing system of centralization of power of the country. They did not bring any change in existing pattern of distribution of power between different types of political and administrative units. They were not inclined to manage for devolution of power and economic resources to political and administrative institutions working with people in village communities. .

The adoption of political and administrative values of Panchayat rule motivated multiparty leaders keep democracy in cage and transform the multiparty type of state system into multiparty variant of dictatorial rule. Through concentrating all powers under their administrative command, they, as managers of the state, held its authority to define themselves the problems and needs of the people, to devise programs for addressing those needs and to implement them into practices through the use of their administrative mechanisms.

Thus, the developmental activities dispensed by the state even under multiparty type of its structure could not appear in the form of right of the people. They were dispensed as targets of the state in the form of its administrative regularities to legitimize its structure. They were distributed in the form of patronage granted to people by those who got hold over power of the state. The state class of $\mathrm{N}$ epal even in the post-1990 period manipulated the power, resources and organizational framework of the state for the expansion of its own advantage.

The problems of the poor remained unchanged even in this period. Like at the time of Panchayat rule, people in rural $\mathrm{N}$ epal continued to face problems associated with scarcity of productive resources and absence of local employment opportunities. They continued to claim over the marginal natural resources or to migrate out from the country for the 
sake of income and employment to satisfy their subsistence necessities.

The multiparty leaders who were in power not only failed to present themselves with people in a democratic manner, they also failed to generate their active support whenever they starkly needed it to give continuity of their rule. They also intensely fought to each other for getting control over the state to use its power in absolute way. Their conflict of power frequently led to breakdown of their mother political organizations as well as the governments run by themselves. The political instability generated by these events provided a fertile ground for the $M$ aoist to expand their organization.

The expansion of organizational base of the NCP (Maoist) further contributed to expand the unstable political situation at the moment. Before 2005, it was working outside the framework existing state organization with a desire to bring in its structure some form of change. However, the state organization from its side was neither interested to transform its structure by accommodating the demands of this political organization, nor was in a position to calm its operations through use of its physical power. The conflicts of interests between the state and the $M$ aoist political organization further intensified the unstable political situation. The state failed even to satisfy its minimum task to ensure security of life of general population.

The failure of the multiparty leaders to generate an active support of people for their rule and the political instability generated by conflict for power among themselves and that between the state and $M$ aoist organization motivated the king to use the situation to make a trial at least once again for the establishment of his absolute rule. This move of the king appeared useful in the sense that it brought together all other forms of political forces to wedge a movement against this step of the king. However, this movement was concluded with an agreement between different types of political forces to bring another wave of change in the structure of state organization.

\section{The Emerging Demands and Their Implications}

The political forces that came together to wage this movement against the king have come to a compromise that the structure of $\mathrm{N}$ epali state to 
be formed in the immediate future will be determined by the Constitution prepared by Constitutional Assembly formed of representatives elected by the people. The state organization that has been operating at the moment is simply an interim arrangement. It has already fulfilled the responsibility to form the Constitutional Assembly through holding an election which is now ready to work to prepare the Constitution.

The Constitutional Assembly will have the task mainly to glean and formalize the possible structure of the state from among multiple demands posed in this regard by different sections of the population. Many of these demands are already in floor and many of the political parties have declared through their election manifestos the level of their commitments and the type of strategies to be followed by them for the fulfillment of these demands. The major issues covered in these demands and related political commitments can be summarized into three broader categories. One of these demands relates to the position of power of monarchy as a living institution. The issues associated with this type of demand are al ready resolved through scraping the existence of this institution. Now there exists no king and the former king of $\mathrm{N}$ epal has agreed to spend a normal life by living in the form a citizen of the country. The second type of demand relates to establish a balance in distribution of power between regional units, and the third type of debate relates to establish this type of balance in the context of groups divided in terms of caste, ethnicity and gender-based attributes.

The demands related to balancing the distribution of power between regional units have been raised since 1950s (Gaige, 1976). They have been raised mainly by those political organizations, which are interested to raise the problems of people of the Tarai region. The Tarai Congress in the past and the Nepal Sadbhawana Party, the Madhesi Janadhikar Forum and the Tarai M adhesh Loktantric Party in present are among the important political organizations, which have posed this type of demand. However, this type of demand gained momentum to emerge in the form of a dominant debate of the country once the $M$ aoists had made its support to this kind of demand. Currently, a number of local, sectoral and/or sub-regional organizations are also actively involved to raise this demand focusing in the case of the Tarai as well as other parts of the country. 
The demands for balancing the distribution of power between caste, ethnic and gender -based social categories were raised at the political level by the $\mathrm{M}$ aoists at the beginning. However, the national and foreign scholars and donor institutions are also intensely involved in the country to explore its reality and promote to this kind of debate (eg.DFID and the World Bank: 2006, Bhattachan et al 2003, Dahal et al 2002, Gellner 1997, FWLD 2005, Pandey et al 2006, and Subba et al 2002,). A number of other social organizations are also formed by people of respective social categories to provide additional support towards the advocacy of these demands. As a result of these developments, this type of demand has been able to emerge as one of the dominant agenda of public debates of the country. Currently, it has taken even the shape of demands of sub-regional units formed of specific types of ethnic categories distributed in different parts of the country.

These three groups of demands differ to each other in one important point. They raise problems focusing on issues of alternative types of social categories. Those who argue in the issue that monarchy as a problem focus their discussion by placing the king in one side of the dichotomized reality and the rest of society in another side. The demands on balancing the distribution of power between regional units also perceive the problem from the point of the Tarai or other regions by comparing them with other parts of the country. The demands related to issues of caste, ethnicity and gender-based categories also appear in similar way. They compare each of these social categories with the rest of society.

However, all these demands hold some level of uniformity as well. They all have the conception that disparity in distribution of power between them and another flank of their dichotomized realities is the basic cause of problems faced by each of these social units. Accordingly, they make the suggestion that the type of problems raised by them can be resolved though creating a balance in distribution power between those dichotomized categories (Bhattachan 1995, Gurung 1997, Lawati 2005, Whelpton 2005).

Indeed, equity in distribution of power is one important indicator of democratic features of society. Equitable distribution of power among different types of social units enables them to enjoy the opportunity of 
life available in society on an equitable basis. It allows them to decide themselves the areas of their choice and devise the related type of strategies. The demands posed by these social units for equitable share in power are, therefore, the demands for enhancing a democratic procedure. A satisfactory fulfillment of these demands of the population can help to reduce chances of concentration of power.

However, the possible effects of these demands for promoting a democratic environment should be understood very cautiously. It has already been mentioned that the perceived cause of problems faced by all members of each of these social categories is the unequal share of the group over distribution of power of society. Consequently, it has been proposed that the problems faced by all members of these groups can be resolved by allowing these groups to have equitable share in distribution of that power. This type of conception is based under the assumption that each of these groups constitutes a homogenous entity. Its members are equal to each other and they do not hold any diversity. The leading advocates of this idea of internal harmony of each group have the perception that the appropriate mechanism to reduce inter-group level of inequality is to ensure for each group to have equitable share over executive, legislative and other types of positions of the state on a proportionate basis (K hanal, 2004).

Thus, the current debates on restructuring the Nepali state have attempted to address the issues of social inequality from the vantage point of ruling circle of society. It puts forward the type of argument that social inequality is a problem mainly faced at the level of ruling elite and its solution should be sought by way of creating a balance in the distribution of resources among different categories of social units. There is no doubt that a change in composition of ruling circle of society is itself a form of change in the structure of the state. It places one group of people into positions of power by displacing the others from having the privilege. It creates a shift in the political and administrative elite of society, which is endowed with power to enjoy different types of privileges.

It is important to mention in this context that some level of attempts had been made after the introduction of multiparty type of political rule 
in the country to open opportunities for different segments of society to have access to these types of privileges through the involvement in competitive processes. However, it is easier for members of the elite to get control over those privileges if the society can preserve the position of power for its members without requiring them to involve into those competitive procedures. Issues related to the need of restructuring the state can have a different type of meaning in the context of problems emerging at the level of relationships developed between the elite and the mass of general people.

In the context of relationship between the ruling elite and general people, state restructuring may require some level of change even in the objectives and policies of the state. It may also require some change in distribution of power among different units of this organization, in feeling of liabilities among members of ruling section of the population, and in the process followed by members of this class in the course of their relationship with the people. The current debates on state restructuring in $\mathrm{N}$ epal do not take into account these of issues of relationship between ruling elite and people in their discussions As a result, these types of debates are of limited importance if they are evaluated from the point of view of the problems faced by people in their relationship with the state. Such a situation indicates to a possibility that the state class of N epal still wants to keep democracy into cage and own the state to use it for its own advantage

\section{What Still Remains to Be Done?}

The detraction of current debates on state restructuring in Nepal to take into account the issues of the patterns of relationship between state class and people indicates that these types of debates need to be oriented also to bring into floor the discussions of problems faced by people through their encounter with this type of relational procedure. It has already been mentioned that the problems emerged for people from this type of relational procedure can be resolved by introducing some change in objectives and policies of the state, in distribution of power among different units formed within its structure, in feeling of liability among members of ruling class of the state, and in the process followed by members of this class in the course of their relationship with the people. 
The policies and rules define the line of relationship between state organization and people. They define authority and privileges of ruling segment of the population. They specify rules related to people's access to resources, their liability to the state, and the types of services they may avail from it as citizens of the state. Debates hold on existing policies related to these and other types of issues and on matters of their impacts on ways of life of the people can help to identify the relevance of those policies and requirements for their change to satisfy the interest and needs of the general people.

One of the important fields requiring changes in bringing some reformulation of relationship between state, state class and people is the organizational structure of the state and the pattern of distribution of power between its units working under that structure. U ntil recently, the power of $\mathrm{N}$ epali state is highly concentrated. It is located in the central organs of the government. The local units of the state organization are used mainly for the expansion of terror of this centralized state in different parts of the country. They are used for the expansion of its control over local level resources. Similarly, they are also used for the dispense of patronage of state class of the country to people of rural localities by way of using them in the form of a mechanism to control and regulate the developmental processes (Pandey, 2004).

Redistribution of power from the center to local units refers to devolution of executive, decision making and economic power of the state to its representative organs of village areas, as they relate to issues and problems of respective localities. This type of change in distribution of power of the state allows some level of freedom to people to identify by themselves the problems faced by them in their localities. It allows them opportunities to allocate and use their resources in a way as they think it appropriate in the context of their problems and other necessities. It is only through this process of redistribution and execution of power that the state appears more accessible to the people. Issues related to such a form of redistribution of power of the state are not raised in the current debates.

Even the debates demanding for autonomous existence of regional units have not paid any attention to define the pattern of relationship 
between them and the local units. Reformulation in existing structure of the state through providing an autonomous authority to regional organs of the governments opens chances for formation and growth of regional elite in society. However, this type of change hardly helps to provide some level of freedom to local population until the relationship of local units with the central and regional units of the governments are separately redefined.

Indeed, devolution of political and economic power of the state to village level units of the government helps to satisfy many of the problems raised in current debates on state restructuring in $\mathrm{N}$ epal. It is a fact that many of the caste and ethnic people are concentrated in some specific parts of the country. As a result, the representative units of the governments in most of those specific localities could be formed of members representing those caste and ethnic people who live there in majority (eg. see Furer-Haimendorf 1964, M acfarlane 1976, etc). D evolution of power of the state to these local units allows these members to use that power for the advantage of their community. It also offers an opportunity for the people to monitor and control the tasks performed in their area by the representatives of their choice selected from their own local society.

Devolution of political and economic power of the state to its local level units also helps to bring some change in the existing pattern of relationship between state class and people. U ntil recently, the state class of the country positioned beyond the village localities has controlled the resources deputed for the development of rural communities. By virtue of its right to control over those resources, it has established for itself in the form of patron of the people to dispense them the "development" activities. The devolution of power to local units can reverse this situation. By providing authority to local people for the control and use of resources allocated for their locality, it brings state class of the country under their administrative command at least in areas of activities performed in their respective communities.

However, current debates on state structuring in $\mathrm{Nepal}$ are less interested to raise issues of relationship of power between local units of the state and its central and regional level organizations. Its interest to 
discuss mainly on issues of distribution of power among different categories of the national and regional elite of society has reduced the issues of relationship of this class with the general people to have hold only a trivial type of importance. Redistribution of power among different segments of the elite simply helps to redistribute the composition of this segment of society. A meaningful restructuring of the state can happen only when the power is redistributed between this elite category and the local people. If this type of issue appears silent in the current wave of state restructuring in Nepal, it leaves room for the next wave to come to bring about this level of change.

\section{R eferences}

A grawal, Hem Narayan 1976, The Administrative System of Nepal: From Tradition to Modernity, New Delhi: Vikash Publishing House.

Baral, Lok Raj (ed.) 2006, Nepal: Quest for Participatory Democracy, New Delhi: Adroit Publishers.

Bhattachan, Krishna, B. 1995. "Ethnopolitics and Ethnodevelopment: An Emerging Paradigm" in Kumar, D hruba (ed.) State Leadership and Politics in Nepal, CNAS, T.U

Bhttachan et. al 2003. Existing Practices of Caste-Based Untochability in Nepal and Strategy for a Campaign for its Elimination, Kathmandu: Action Aid $\mathrm{N}$ epal

Dahal, Dilli, R. et al 2002. National Dalit Strategy. Kathmandu: Action Aid/ Care Nepal

DFID and the W orld Bank 2006. The Unequal Citizens, Kathmandu: DFID and the World Bank

Dunn, John 1969. The Political Thought of J ohn Lock, Cambridge: Cambridge University Press.

Evans, Petter, D etrich Ruschemeyer and Theda Skocpol, (eds.) 1985. Bringing the State Back In, USA: Cambridge University Press.

Forum for Women Law and Development (FWLD) 2005. An Update of the Discriminatory Laws in Nepal and Their Impact on Women (Draft). $K$ athmandu, Forum for women, Law and Development

Gellner David N. J oanna Pfaff-Czarnecka and J ohn Whelpton (eds. ). Nationalism and Ethnicity in a Hindu Kingdom: The Politics of Culture in Contemporary 
Nepal, The Netherlands: Hardwood Academic Publishers.

Gupta, A nirudha 1964. The Politics of Nepal: A Study of Post-Rana Political Development and Party Politics. New Delhi: Allied Publishers.

Gurung, Harka 1997, "State and Society in Nepal" in Gellner David N. J oanna Pfaff-C zarnecka and J ohn Whelpton (eds.) Nationalism and Ethnicity in a Hindu Kingdom: The Politics of Culture in Contemporary Nepal. The Hethrelands: Hardwood A cademic Publishers.

Gaige, Fredrick H. 1976. Regionalism and National Unity in Nepal. New Delhi: Sage Publication

Hood, Steven J. 2004. Political Development and D emocratic Theory: Rethinking Comparative Politics, New Delhi: Printice-Hall of India.

Jessop, B ob 1990. State Theory: Putting the Capital State in Its Place, Cambridge: Polity Press.

J ordan, Bill 1985. The State: Authority and Autonomy. N ew Y ork: Basil Blackwell.

K hanal, Krishna 2004. State Restructuring in Nepal. Kathmandu: Nepal Centre for Contemporary Studies

Kumar, Satish 1961. Rana Policy in Nepal: Origin and Growth. Bombay: A sia Publishing House.

Lawati, M ahendra 2005. Towards a Democratic Nepal: Inclusive Political Institutions for a Multicultural Society. New Delhi: Sage Publications

L indbolm, Charles 1978. Democracy and Market System. Norwey: Norwegian University Press.

M igdal, J oel S. 1988. Strong Societies and Week States: State-Society Relations and State Capabilities in the Third World: N ew Jersey: Princeton U niversity Press.

M iliband, Ralph 1969. The State in Capitalist Society. N ew Y ork: Basic Books.

M oore, Barrington JR. 1966. Social Origin of Dictatorship and Democracy: Lords and Peasants in the Making of the Modern World. USA: Penguin University Press.

Poulantza, Nicos 1973. Political Power and Social Classes. Translated by Gagan, Timothy $0^{\prime}$, Bristol: Western Printing Services.

Pandey, Tulsi R. et al 2006. Forms and Patterns of Social Discrimination in Nepal, Series of Monographs and Working Papers No. 8, Kathmandu: UNESCO. 
Pandey, Tulsi R. 2004, Household, Community and the State: A Study of M odes of Livelihoods in the Hill and Tarai Villages of Western Nepal, Ph.D. Thesis Submitted to Delhi School of Economics, University of Delhi

Regmi, Mahesh . C 1978. Land Tenure and Taxation In Nepal. Kathmandu: Ratna Pustak Bhandar.

Rosenberg, N. 1960, "Some Institutional A spects of W ealth of Nations" inj ournal of Political Economy, Vol. 18, N o. 6, pp. 557-570.

Sen, A martya 2000. Development as F reedom. N ew Delhi: Oxford University Press.

Stiller, S.J, Ludwig F. 1973. The Rise of the House of Gorkha: A Study in Unification of Nepal, New Delhi: M anjushree Publishing House.

Stiller, S.J, Ludwig F. and Ram Prakash Yadav 1979. Planning For People. Kathmandu: Sahayogi Prakashan

Subba, Chaitanya, Amrit Yonjan, Nilambar Acharya, Laxmi Limbu, Shyam Krishna Shrestha, Sangini Ranamagar, Dwarika Nath Dhungel. 2002. Adivasis/J anajatis in National Development : Major Issues, Constraints and Opportunities (Plan of Action Proposed for the Tenth Plan, 2003-2007)

Weber, M ax 1948. Essays in Sociology, Translated by Gerth H.H. and C Write Mills, London: Rutledge and Kegan Paul

Whelpton, John, 2005. A History of Nepal. Cambridge University Press: UK 